\title{
ASUPAN ENERGI CEMILAN, DURASI DAN KUALITAS TIDUR PADA REMAJA OBESITAS DAN NON OBESITAS
}

\author{
Viony Vira Agita ${ }^{1}$, Nurmasari Widyastuti ${ }^{1}$, Choirun Nissa $^{1}$ \\ ${ }^{1}$ Departemen Ilmu Gizi, Fakultas Kedokteran, Universitas Diponegoro \\ Jln. Prof. H. Soedarto, SH., Semarang, Telp (024) 76402881, Email : gizifk@undip.ac.id
}

\begin{abstract}
Background: Snack energy intake, duration and sleep quality is one of the risk factors for obesity. Adolescents obesity usually consume excessive snack energy intake, has a short duration of sleep, and poor sleep quality.

Objective: This study aims to determine whether there are differences in snack energy intake, duration and sleep quality in obese adolescents and non obese age 15-18 years.

Methods: This study was an observational study with cross sectional design. A total of Subjects in 25 people into the obese group and 25 people are non-obese group. All subjects were interviewed using a screening questionnaire, pittsburgh sleep quality index, semi-quantitative food frequency, and short form of international physical activity. Statistical analysis using independent t test, and Mann Whitney.

Results: The difference of snack energy intake $(p=<0.001)$, sleep duration $(p=0,415)$, sleep quality $(p=\langle 0.001)$ in obese and non obese group.

Conclusion: There is a difference in snack energy intake and sleep quality in obese and non obese groups. There is no difference in sleep duration of obese and non obese groups.
\end{abstract}

Keywords: Snack energy intake, sleep duration, sleep quality, adolescence, obesity

\begin{abstract}
ABSTRAK
Latar belakang: Asupan energi cemilan, durasi dan kualitas tidur merupakan salah satu faktor risiko terjadinya obesitas. Remaja obesitas biasa mengasup asupan energi cemilan berlebih, memiliki durasi tidur yang pendek, serta kualitas tidur yang buruk. Penelitian ini bertujuan untuk mengetahui apakah terdapat perbedaan asupan energi cemilan, durasi dan kualitas tidur pada remaja obesitas dan non obesitas usia 15-18 tahun.

Metode: Jenis penelitian ini merupakan penelitian observasional dengan rancangan desain cross sectional. Subjek sebanyak 25 orang masuk ke dalam kelompok obesitas dan 25 orang merupakan kelompok non obesitas. Semua subjek diwawancara menggunakan kuesioner skrining, indeks kualitas tidur pittsburgh, frekuensi makan semi kuantitatif, dan formulir singkat aktifitas fisik internasional. Analisis statistik menggunakan uji independent t test, dan Mann Whitney.

Hasil: Nilai perbedaan asupan energi cemilan ( $p=<0,001)$, durasi tidur $(p=0,415)$, kualitas tidur $(p=<0,001)$ pada kelompok obesitas dan non obesitas.

Kesimpulan: Terdapat perbedaan asupan energi cemilan dan kualitas tidur pada kelompok obesitas dan non obesitas. Tidak terdapat perbedaan durasi tidur pada kelompok obesitas dan non obesitas.
\end{abstract}

Kata kunci : Asupan energi cemilan, durasi tidur, kualitas tidur, remaja, obesitas

\section{PENDAHULUAN}

Kelebihan berat badan atau obesitas merupakan masalah kesehatan yang dapat berkontribusi terhadap peningkatan masalah kesehatan atau penyakit tidak menular kronis seperti diabetes tipe 2, hipertensi, dan penyakit kardiovaskular. ${ }^{1}$ Prevalensi obesitas telah meningkat dan dianggap sebagai ancaman kesehatan masyarakat dibanyak negara khususnya negara berkembang. ${ }^{2}$ Obesitas pada remaja juga dapat berhubungan dengan kejadian obesitas dan peningkatan risiko komorbiditas ketika dewasa. ${ }^{3,4}$ Periode remaja merupakan salah satu periode kritis dalam masa tumbuh kembang anak kaitannya dengan terjadinya obesitas. ${ }^{5} \quad$ Perubahan kognitif, fisik, sosial dan gaya hidup selama remaja dapat membuat banyak perubahan termasuk pada pola makan, remaja banyak menghabiskan waktu diluar rumah (membuat tugas di cafe atau restoran cepat saji) yang dapat membuat remaja lebih mengkonsumsi cemilan mengandung tinggi kalori dan berpengaruh terhadap kejadian obesitas pada remaja. ${ }^{6-10}$ Menurut penelitian $80 \%$ remaja yang obesitas akan menjadi dewasa yang obesitas. ${ }^{5}$ Remaja yang mengalami obesitas akan terjadi peningkatan risiko penyakit kardiovaskular hingga lebih dari $34 \%$ dimasa dewasa. ${ }^{11}$

Prevalensi berat badan berlebih pada remaja Indonesia mengalami kenaikan dari waktu ke waktu. Data dari Riskesdas menunjukkan prevalensi berat badan berlebih pada remaja usia 16-18 tahun meningkat dari 1,4\% (2010) menjadi 7,3\% (2013), dimana terdiri dari $5,7 \%$ gemuk dan $1,6 \%$ obesitas. ${ }^{12}$ 
Jawa tengah merupakan salah satu dari lima belas provinsi dengan prevalensi obesitas diatas prevalensi nasional.Prevalensi gizi lebih secara nasional pada remaja usia 13-15 tahun (2010) di Indonesia sebesar $10,8 \%$, terdiri dari $8,3 \%$ gemuk dan 2,5 persen obesitas, sedangkan di Jawa Tengah sebesar 2,8\% remaja mengalami obesitas. ${ }^{13}$

Obesitas pada remaja banyak dipengaruhi oleh berbagai faktor risiko seperti asupan zat gizi, durasi dan kualitas tidur, serta sedentary lifestyle. ${ }^{14,15}$ Penelitian pada remaja di Bahrain memberikan kesimpulan bahwa remaja yang gemar menghabiskan waktu didepan layar (menonton televisi,video game, dll) selama lebih dari 3 jam perhari dapat berpengaruh terhadap peningkatan asupan energi. ${ }^{11} \mathrm{Hal}$ ini dikarenakan adanya konsumsi cemilan yang padat energi di saat menonton televisi seperti fast food (kentang goreng, burger). ${ }^{16}$

Makanan ringan atau cemilan biasa dikonsumsi diluar makanan utama, dan dibagi menjadi beberapa kali sehari, baik pagi, siang, sore, dan malam. Penelitian di Australia pada anak sekolah menunjukkan terdapat hubungan yang signifikan pada kejadian obesitas dengan kebiasaan makan berupa kebiasaan konsumsi asupan energi cemilan (makanan dan minuman tinggi energi). Konsumsi cemilan memberikan kontribusi terhadap tingginya asupan energi, lemak, dan gula namun sedikit akan zat gizi mikro. ${ }^{17}$

Durasi tidur yang pendek, kualitas tidur yang buruk akan menyebabkan peningkatan konsumsi cemilan sehingga berkontribusi terhadap asupan energi dan berdampak pada obesitas. ${ }^{18,19}$ Durasi tidur yang pendek (2-4 jam sehari) berhubungan terhadap perubahan hormon orexins, diantaranya leptin dan ghrelin yang dapat berhubungan dengan risiko terjadinya obesitas. ${ }^{20,21}$

Kualitas tidur merupakan kepuasan seseorang terhadap tidur, sehingga dapat bangun tidur dengan keadaan segar, tidak gelisah, tidak lesu, dan tidak sering menguap atau mengantuk. ${ }^{22}$ Kualitas tidur yang buruk menyebabkan kelelahan setelah bangun tidur, dan penurunan aktifitas fisik, sehingga terjadi peningkatan sedentary lifestyle yang dapat berpengaruh dengan obesitas. ${ }^{23}$

Penelitian serupa mengenai asupan energi cemilan, durasi dan kualitas tidur yang dikaitkan dengan kegemukan pada remaja usia 15-18 tahun masih jarang dilakukan di Indonesia khususnya Semarang. Berdasarkan uraian di atas maka dapat dikembangkan penelitian mengenai perbedaan asupan energi cemilan, durasi dan kualitas tidur pada remaja obesitas dan non obesitas usia 15-18 tahun. Penelitian ini diharapkan dapat memberikan informasi untuk membantu menangani masalah kegemukan pada remaja dengan memperhatikan asupan energi cemilan, durasi dan kualitas tidur, sehingga dapat diterapkan program penanganan yang lebih tepat.

\section{METODE}

Penelitian ini merupakan penelitian observasional dengan pendekatan cross sectional. Penelitian dilaksanakan di SMA N 15 Semarang dengan sampel siswa siswi berusia 15-18 tahun. Besar sampel dalam penelitian ini dihitung dengan rumus uji hipotesis terhadap rerata dua populasi independen. Sampel yang dibutuhkan dalam penelitian ini minimal 50 orang terbagi menjadi 2 kelompok masing-masing 25 orang. Kriteria inklusi antara lain remaja berusia 15-18 tahun, sehat dan tidak sedang dalam proses penggunaan obat atau suplemen penurun BB, mampu berkomunikasi dengan baik, remaja berdasarkan IMT/U dengan nilai Z-Score >2 SD serta remaja berdasarkan IMT/U dengan nilai Z-Score $-2 \mathrm{SD}$ sampai $1 \mathrm{SD}$, dan bersedia menjadi sampel penelitian dengan mengisi informed-consent penelitian. Pengambilan sampel diawali dengan skrining pada 288 remaja, dari nilai IMT/U ditemukan 25 remaja obesitas, 23 remaja kurus, serta 240 remaja normal. Pemilihan 25 sampel penelitian pada masing-masing kelompok dilakukan secara consecutive sampling.

Variabel bebas dalam penelitian ini adalah asupan energi cemilan, durasi dan kualitas tidur. Variabel perancu dalam penelitian ini adalah asupan energi, lemak, karbohidrat, protein, serat, dan aktivitas fisik. Variabel terikat dalam penelitian ini adalah obesitas. Data yang diambil dalam penelitian ini antara lain data identitas sampel (nama, usia, tanggal lahir, jenis kelamin, alamat, nomer telepon dan konsumsi obat / suplemen penurun BB ), data antropometri (tinggi badan dan berat badan), data asupan energi cemilan, data durasi dan kualitas tidur, data asupan zat gizi (energi, karbohidrat, lemak, protein, dan serat), dan data aktivitas fisik.

Data identitas sampel diperoleh melalui wawancara langsung kepada subyek penelitian. Data asupan energi cemilan dan data asupan zat gizi diperoleh dari pengisian Semi Quantitative Food Frequency Questionnaire (SQ-FFQ), untuk data asupan energi cemilan, dianalisis menggunakan software komputer lalu dibandingkan dengan kebutuhan masing-masing subyek lalu dikategorikan menjadi berlebih (>30\%) dan tidak berlebih $(<30 \%),{ }^{24}$ sedangkan data total asupan zat gizi dianalisis menggunakan software komputer lalu dibandingkan dengan kebutuhan masing-masing subyek dan dikategorikan menjadi berlebih $(\geq 110 \%)$ dan tidak berlebih $(<110 \%)$. ${ }^{25}$ Data durasi tidur dan kualitas tidur diperoleh dari pengisian kuesioner Pittsburgh Sleep Quality Index(PSQI), untuk 
mengetahui data durasi tidur dengan menggunakan pertanyaan nomor 4 , kemudian hasil pengukuran dikategorikan menjadi kurang $(<8,5$ jam/hari) dan cukup (8,5-9,25 jam/hari), ${ }^{26}$ sedangkan data kualitas tidur diperoleh dari pengisian kuesionerterdiri dari seluruh 9 pertanyaan yang terdapat dalam kuesioner, apabila jumlah hasil skor pertanyaan $\leq 5$ maka kualitas tidur dinilai baik dan apabila jumlah hasil skor pertanyaan >5-21 maka kualitas tidur dinilai buruk. ${ }^{27}$ Aktivitas fisik subjek diukur menggunakan short International Physical Activity Quetionnaire (IPAQ - SF) melalui recall aktivitas fisik selama 7 hari terakhir, kemudian hasil perhitungan dikategorikan menjadi aktif (600-3000 MET/menit/minggu) dan tidak aktif $(<599$ MET/menit/minggu). ${ }^{28}$

$$
\text { Analisis data statistik }
$$

menggunakankomputer.Analisis univariat dilakukan untuk mendeskripsikan variabel. Uji kenormalan data menggunakan Kolmogorov-Smirnov. Analisis bivariat dilakukan untuk mengetahui perbedaan masing-masing variabel dengan variabel terikat menggunakan uji independent $t$ test apabila data berdistribusi normal, apabila data berdistribusi tidak normal menggunakan uji Mann Whitney.

\section{HASIL PENELITIAN}

\section{Karakteristik Subjek Penelitian}

Total subjek pada penelitian ini sebanyak 50 yang terdiri dari 25 remaja obesitas dan 25 remaja non obesitas usia 15-18 tahun. Kelompok obesitas memiliki nilai z-score 2,02 hingga 3,52 sementara kelompok non obesitas memiliki nilai z-score $-1,04$ hingga 0,92 .

Tabel 1. Karakteristik Subjek

\begin{tabular}{lllllll}
\hline \multirow{2}{*}{ Karakteristik } & \multicolumn{3}{c}{ Kelompok obesitas $(\mathbf{n = 2 5})$} & \multicolumn{3}{c}{ Kelompok non obesitas(n=25) } \\
\cline { 2 - 7 } & \multicolumn{1}{c}{ Mean \pm SDD } & \multicolumn{1}{c}{ Min } & \multicolumn{1}{c}{ Maks } & \multicolumn{1}{c}{ Mean \pm SD } & \multicolumn{1}{c}{ Min } & \multicolumn{1}{c}{ Maks } \\
\hline Usia (tahun) & $15,53 \pm 0,31$ & 15,00 & 16,17 & $15,58 \pm 0,49$ & 15,00 & 16,67 \\
Berat badan (kg) & $83,51 \pm 10,07$ & 65,00 & 102,40 & $53,65 \pm 5,48$ & 40,70 & 64,00 \\
Tinggi badan(kg) & $163,53 \pm 6,69$ & 151,20 & 174,00 & $159,63 \pm 6,66$ & 149,90 & 174,00 \\
IMT/U (z-score) & $2,40 \pm 0,40$ & 2,02 & 3,52 & $0,27 \pm 0,47$ & $-1,04$ & 0,92 \\
\hline
\end{tabular}

Tabel 2. Distribusi Frekuensi Kategori Asupan Energi Cemilan,Durasi Tidur, Kualitas Tidur, Aktivitas Fisik, Asupan Zat Gizi

\begin{tabular}{|c|c|c|c|c|}
\hline \multirow[t]{2}{*}{ Variabel } & \multicolumn{2}{|c|}{$\begin{array}{c}\text { Kelompok obesitas } \\
(\mathbf{n}=25)\end{array}$} & \multicolumn{2}{|c|}{$\begin{array}{c}\text { Kelompok nonobesitas } \\
(\mathbf{n}=\mathbf{2 5})\end{array}$} \\
\hline & $\mathbf{n}$ & $\%$ & $\mathbf{n}$ & $\%$ \\
\hline \multicolumn{5}{|l|}{ Asupan energi cemilan } \\
\hline lebih & 24 & 96 & 3 & 12 \\
\hline tidak lebih & 1 & 4 & 22 & 88 \\
\hline \multicolumn{5}{|l|}{ Durasi tidur } \\
\hline kurang & 20 & 80 & 19 & 76 \\
\hline cukup & 5 & 20 & 6 & 24 \\
\hline \multicolumn{5}{|l|}{ Kualitas tidur } \\
\hline buruk & 16 & 64 & 4 & 16 \\
\hline baik & 9 & 36 & 21 & 84 \\
\hline \multicolumn{5}{|l|}{ Aktivitas fisik } \\
\hline tidak aktif & 13 & 52 & 7 & 28 \\
\hline aktif & 12 & 48 & 18 & 71 \\
\hline \multicolumn{5}{|l|}{ Asupan energi } \\
\hline lebih & 11 & 44 & 0 & 0 \\
\hline tidak lebih & 14 & 56 & 25 & 100 \\
\hline \multicolumn{5}{|l|}{ Asupan karbohidrat } \\
\hline lebih & 6 & 24 & 0 & 0 \\
\hline tidak lebih & 19 & 76 & 25 & 100 \\
\hline \multicolumn{5}{|l|}{ Asupan lemak } \\
\hline Lebih & 18 & 72 & 7 & 28 \\
\hline tidak lebih & 7 & 28 & 18 & 72 \\
\hline \multicolumn{5}{|l|}{ Asupan protein } \\
\hline lebih & 5 & 20 & 0 & 0 \\
\hline tidak lebih & 20 & 80 & 25 & 100 \\
\hline \multicolumn{5}{|l|}{ Asupan serat } \\
\hline tidak lebih & 25 & 100 & 25 & 100 \\
\hline lebih & 0 & 0 & 0 & 0 \\
\hline
\end{tabular}


Tabel 3. Asupan Energi Cemilan,Durasi Tidur, KualitasTidur, Aktivitas Fisik, Asupan Zat Gizi

\begin{tabular}{|c|c|c|c|c|c|c|c|}
\hline \multirow{2}{*}{ Karakteristik } & \multicolumn{3}{|c|}{ Kelompok obesitas $(\mathrm{n}=25)$} & \multicolumn{3}{|c|}{ Kelompok non obesitas $(\mathrm{n}=25)$} & \multirow[t]{2}{*}{ Nilai p } \\
\hline & Mean \pm SD & Min & Maks & Mean \pm SD & Min & Maks & \\
\hline $\begin{array}{l}\text { Asupan energi cemilan } \\
\text { (Kkal) }\end{array}$ & $\begin{array}{l}1256,20 \pm 258 \\
51,2504 \pm-\end{array}$ & 592,00 & 1639,60 & $388 \pm 139,9$ & 126,00 & 783,60 & $<0,001^{\mathrm{a}}$ \\
\hline $\begin{array}{l}\text { Presentase energi cemilan } \\
\text { dalam total energi }(\%)\end{array}$ & & 28,32 & 63,40 & $18,625 \pm-$ & 6,00 & 35,11 & - \\
\hline Durasi tidur (jam) & $6,92 \pm 0,81$ & 5,50 & 8,50 & $7,04 \pm 0,99$ & 4,00 & 8,50 & $0,415^{\mathrm{b}}$ \\
\hline Kualitas tidur (skor) & $6,16 \pm 1,67$ & 2,00 & 9,00 & $5,32 \pm 1,88$ & 2,00 & 9,00 & $<0,001^{\mathrm{b}}$ \\
\hline $\begin{array}{l}\text { Aktivitas fisik (MET- } \\
\text { menit/minggu) }\end{array}$ & $956,1 \pm 661,5$ & 388,5 & 2280 & $1640,7 \pm 1126$ & 219,00 & 3780,00 & $0,019^{\mathrm{b}}$ \\
\hline Asupan energi (Kkal) & $2764,5 \pm 395,8$ & 2026,10 & 3340,40 & $1539,5 \pm 153,0$ & 1127,10 & 1760,20 & $<0,001^{\mathrm{b}}$ \\
\hline Asupan karbohidrat (g) & $386,6 \pm 58,9$ & 273,7 & 509,1 & $199,74 \pm 36,03$ & 121,90 & 249,40 & $<0,001^{\mathrm{a}}$ \\
\hline Asupan lemak (g) & $87,06 \pm 16,69$ & 41,90 & 112,30 & $60,60 \pm 10,67$ & 30,70 & 89,70 & $<0,001^{\mathrm{a}}$ \\
\hline Asupan protein (g) & $93,1 \pm 16,77$ & 51,70 & 115,20 & $50,63 \pm 7,06$ & 37,70 & 64,50 & $<0,001^{\mathrm{b}}$ \\
\hline Asupan serat $(\mathrm{g})$ & $14,56 \pm 3,36$ & 9,00 & 24,20 & $8,25 \pm 3,25$ & 3,70 & 15,40 & $<0,001^{\mathrm{b}}$ \\
\hline
\end{tabular}

${ }^{\mathrm{a}}$ Independent T-test; ${ }^{\mathrm{b}}$ Mann-Whitney U test

Asupan Energi Cemilan, Durasi Tidur, Kualitas Tidur, Aktivitas Fisik, Asupan Zat Gizi

Hasil penelitian menunjukkan remaja obesitas memiliki asupan energi cemilan dengan kategori lebih, dan asupan zat gizi lebih banyak dibandingkan remaja non obesitas. Asupan serat pada kedua kelompok memiliki asupan yang tidak lebih, dilihat dari jumlah rerata supan serat pada kelompok obesitas lebih tinggi dibandingkan rerata asupan serat kelompok non obesitas. Bila dilihat pada kuesioner, kelompok obesitas lebih banyak mengkonsumsi makanan baik dalam jenis dan frekuensi seperti konsumsi sayur pada waktu makan utama, sedangkan pada kelompok non obesitas mengkonsumsi makanan lebih sedikit baik dalam jenis dan frekuensi dalam makan utama, namun asupan serat pada remaja obesitas dan non obesitas masih kurang dengan standar kecukupan serat pada AKG sebesar 30-37 gram. Remaja obesitas memiliki durasi tidur yang kurang, dan kualitas tidur yang buruk serta aktifitas fisik yang tidak aktif lebih banyak dibandingkan remaja non obesitas.

Berdasarkan analisis bivariat, diperoleh hasil bahwa terdapat perbedaan asupan energi cemilan, kualitas tidur, aktifitas fisik, asupan energi, karbohidrat, lemak, protein, dan serat antara kelompok obesitas dan non obesitas $(\mathrm{p}<0,05)$, namun ditemukantidak terdapat perbedaan durasi tidur antara kelompok obesitas dan non obesitas ( $p>0,05)$.

Jenis cemilan yang sering dikonsumsi pada remaja obesitas terdiri dari produk bakery, dan makanan cepat saji, pada remaja non obesitas jenis cemilan yang sering dikonsumsi lebih mengarah pada kripik singkong dan tempe. Remaja obesitas juga memiliki durasi tidur yang pendek yaitu 7-8 jam/hari, hampir sama jika dibandingkan dengan remaja non obesitasyaitu 7,5-8,5 jam/hari. Apabila dilihat pada kuesioner kualitas tidur remaja obesitas banyak menilai kurang puas terhadap tidur, mereka menganggap waktu tidur mereka kurang karena banyaknya tugas dan tuntutan belajar dari sekolah, pada kuesioner kualitas tidur remaja non obesitas didapatkan mereka sering mengantuk ketika melakukan aktivitas fisik disiang hari.

\section{PEMBAHASAN \\ Karakteristik Subjek Penelitian}

Kejadian obesitas dari waktu ke waktu mengalami peningkatan.Hasil penelitian ini menunjukkan dari total 288 siswa siswi, terdapat $12 \%$ yang memiliki berat badan berlebih dengan jenis kelamin laki-laki berjumlah 12 orang dan perempuan 13. Jumlah ini meningkat dibandingkan angka kejadian pada tahun 2013 di Indonesia yaitu 7,3\%. Selanjutnya dilakukan analisis bivariat untuk mengetahui perbedaan asupan energi cemilan, durasi tidur dan kualitas tidur terhadap kejadian obesitas.

Asupan Energi Cemilan, Durasi Tidur, Kualitas Tidur, Asupan Zat Gizi, Aktivitas Fisik

Analisis bivariat menunjukkan adanya perbedaan asupan energi cemilan antara remaja obesitas dengan non obesitas. Hasil penelitian ini menunjukkan asupan cemilan dengan energi berlebih banyak dikonsumsi oleh remaja obesitas dibandingkan remaja non obesitas. Subjek obesitas lebih banyak mengkonsumsi cemilan diantara waktu sesudah makan utama, dan paling banyak pada sore sampai malam hari.Jenis makanan cemilan yang sering dikonsumsi oleh subjek obesitas diantaranya roti kering, coklat, kentang goreng, burger, dan aneka gorengan, dan kebanyakan remaja obesitas mengkonsumsi cemilan diimbangi dengan minuman manis seperti es coklat dan minuman bersoda, sedangkan subjek non obesitas lebih sedikit dalam mengkonsumsi cemilan dibandingkan remaja 
obesitas. Subjek non obesitas lebih banyak mengkonsumsi cemilan diantara waktu sesudah makan utama, dan paling banyak pada siang hari, remaja non obesitas lebih gemar mengkonsumsi cemilan yang tidak mengandung minyak berlebih seperti aneka keripik, dan kebanyakan remaja non obesitas mengkonsumsi cemilan diimbangi dengan minuman seperti es jeruk, dan es sirup.

Persentase rerata jumlah energi cemilan yang dikonsumsi oleh remaja obesitas dan non obesitas menunjukkan sebesar $51,25 \%$ jumlah persentase energi yang dikonsumsi oleh remaja obesitas perhari, apabila dilihat jumlah persentase ini melebihi dari jumlah batasan persentase energi yang harus dikonsumsi oleh remaja sebesar $30 \%$ perharinya, ${ }^{24}$ sedangkan sebesar 18,62\% jumlah presentase energi cemilan oleh remaja non obesitas. Jumlah presentase asupan energi cemilan yang melebihi dari jumlah standar tersebut akan meningkatkan risiko kajadian obesitas pada remaja. ${ }^{24}$

Konsumsi cemilan memberikan kontribusi terhadap tingginya asupan energi, dan zat gizi makro lain. Hasil penelitian sejalan dengan studi lain yang telah dilakukan bahwa responden obesitas lebih memilih konsumsi cemilan yang padat energi seperti kue dan fast food dibandingkan jenis cemilan lain. ${ }^{29}$ Faktor lain yang berkontribusi terhadap obesitas diantaranya kualitas dan durasi tidur remaja

Analisis bivariat selanjutnya menunjukkan adanya perbedaan kualitas tidur antara remaja obesitas dengan non obesitas. Hasil penelitian ini menunjukkan kualitas tidur yang buruk lebih banyak dialami oleh remaja obesitas dibandingkan dengan remaja non obesitas. Pada penelitian ini dengan hasil kuesioner PSQI menunjukkan rata-rata remaja obesitas mengalami masalah tidur yang dapat berdampak pada aktivitas disiang hari dan mereka menilai memiliki kepuasan tidur yang kurang.Hasil kuesioner PSQI pada remaja non obesitasmenunjukkan bahwa mereka dapat menilai kepuasaan tidur yang cukup baik.

Kualitas tidur yang buruk menyebabkan kelelahan setelah bangun tidur, dan penurunan aktifitas fisik, sehingga terjadi peningkatan sedentary lifestyle, seperti menonton televisi dan bermain computer/video games. Penelitian Hanley et al pada masyarakat Kanada menemukan bahwa remaja usia 10-19 tahun yang menonton televisi >5 jam per hari, secara signifikan lebih berpeluang mengalami gizi lebih dibandingkan dengan remaja yang hanya menonton televisi $\leq 2$ jam per hari. ${ }^{30}$ Menonton televisi termasuk dalam gaya hidup sedentaris (sedentary lifestyle) yaitu gaya hidup santai dan meminimalisasikan aktivitas fisik. Menonton televisi tergolong dalam aktivitas ringan yang berarti tidak banyak energi yang terpakai, apabila menonton televisi dalam waktu yang lama dan diiringi dengan konsumsi cemilan padat energi, maka dapat terjadi ketidakseimbangan energi di dalam tubuh,dandapat berkontribusi memperbesar risiko kejadian gizi berlebih. ${ }^{31,32}$

Beberapa penelitian juga menunjukkan bahwa kualitas tidur yang buruk dapat terkait dengan faktor sosial seperti kesulitan dalam mengatasi masalah, meningkatnya kecemasan, ketegangan, dan dapat berpengaruh negatif pada konsentrasi belajar. ${ }^{33,34}$ Faktor sosial tersebut dapat disebabkan karena efek fisiologis dari hormon epinefrin yang dapat memicu reaksi yang sering dirasakan seperti frekuensi detak jantung meningkat,keringat dingin dan keterkejutan atau shok. Keadaan stres akan merangsang pengeluaran hormon epinefrin secara berlebihan sehingga menyebabkan jantung berdebar keras dan cepatyang dapat berpengaruh terhadap kualitas tidur, perasaan cepat lelah, mudah terusik, kepala pusing, dan sebagianya. ${ }^{35}$ Berdasarkan temuan terhadap beberapa penelitian mengenai kualitas tisur, indikator kualitas tidur seseorang yang cukup yaitu tidak terjaga lebih dari sekali selama lima menit di malam hari, tertidur kurang dari 30 menit atau 60 menit untuk usia diatas 65 tahun, untuk dapat mendapatkan kualitas tidur yang cukup, seseorang harus memiliki perasaan santai seperti mendengarkan musik sebelum tidur. ${ }^{36}$ Kuesioner PSQI juga dapat menilai data durasi tidur remaja.

Durasi tidur tidak menunjukkan adanya perbedaan antara kelompok obesitas dan non obesitas, dalam penelitian lebih banyak kelompok obesitas menunjukkan durasi tidur yang kurang walaupun secara statistik tidak signifikan, berdasarkan informasi saat pengambilan data kebanyakan memiliki durasi tidur yang pendek antara remaja obesitas dan non obesitas, karena mereka dituntut dengan lingkungan belajar yaitu dalam mengerjakan tugas sekolah. Penurunan durasi tidur pada seseorang dapat dipengaruhi oleh perasaan dan pikiran seseorang, seperti stress dan rasa cemas. ${ }^{37}$ Terdapat variabel perancu yang dapat berkontribusi terhadap kejadian obesitas, seperti asupan zat gizi dan aktivitas fisik.

Variabel perancu dalam penelitian ini yang terdapat perbedaan antara kelompok obesitas dengan non obesitas adalah asupan energi, karbohidrat, lemak, protein, serat, dan akivitas fisik. Asupan energi berlebih lebih banyak dikonsumsi oleh remaja obesitas. Dalam kuesioner SQ-FFQ didapatkan remaja obesitas lebih banyak mengkonsumsi makanan dengan padat energi seperti mie instan dalam waktu hampir $2 x$ dalam sehari.Sedangkan pada remaja non obesitas mengkonsumsi mie instan hampir 3 hari sekali. 
Dari persentase rerata jumlah energi total yang dikonsumsi oleh remaja obesitas dan non obesitas menunjukkan sebesar $110,171 \%$ jumlah persentase energi yang dikonsumsi oleh remaja obesitas perhari, apabila dilihat jumlah persentase ini melebihi dari jumlah batasan energi yang harus dikonsumsi oleh remaja, sedangkan sebesar $73,4 \%$ rerata jumlah persentase energi yang dikonsumsi oleh remaja non obesitas perhari, dan apabila dilihat jumlah persentase ini tidak melebihi batasan jumlah persentase energi yang harus dikonsumsi oleh remaja yaitu sebesar $\geq 110 \%$ perharinya. ${ }^{25}$

Obesitas dapat disebabkan oleh tidak adanya keseimbangan energi yaitu apabila asupan melebihi pengeluaran dan peningkatan biaya yang rendah untuk membeli konsumsi makanan padat energi seperti mie instan dapat merupakan faktor pendukung bagi epidemi obesitas AS. Hasil penelitian ini sejalan dengan penelitian yang dilakukan pada remaja SLTP di Kota Yogyakarta bahwa terdapat perbedaan asupan energi total dengan kejadian obesitas dan non obesitas. ${ }^{38}$

Asupan karbohidrat berlebih lebih banyak dikonsumsi oleh remaja obesitas. Dalam kuesionerSQ-FFQ didapatkan remaja obesitaslebih banyak mengkonsumsi makanan dengan kandungan karbohidrat tinggi seperti nasi yang sering dikonsumsi sebagai makanan utama dengan 2,5-3 centong sekali makan. Sedangkan pada remaja non obesitas mengkonsumsi nasi pada makanan utama 1,5-2 centong sekali makan. Sebagian karbohidrat di dalam tubuh berada dalam sirkulasi darah sebagai glukosa untuk keperluan energi, sebagian disimpan sebagai glikogen hati dan jaringan otot dan sebagian diubah menjadi lemak. Seseorang yang mengkonsumsi karbohidrat dalam jumlah berlebih akan menjadi kegemukan karena kelebihan karbohidrat di dalam tubuh diubah menjadi lemak. ${ }^{39}$

Asupan lemak berlebih lebih banyak dikonsumsioleh remaja obesitas. Dalam penelitian ini makanan cepat saji banyak dikonsumsi oleh kelompok obesitas dibandingkan dengan kelompok non obesitas, remaja obesitas lebih gemar mengkonsumsi makanan cepat saji seperti aneka produk olahan yang digoreng, sedangkan pada remaja non obesitas jarang mengasup asupan makanan cepat saji, pada umumnya makanan cepat saji mengandung lemak dan gula yang tinggi menyebabkan obesitas.Pola makan subjek obesitas telah diketahui mengandung 5-8 \% lebih tinggi lemak dari makanan orang dengan berat badan normal. Hasil penelitian ini sejalan dengan penelitian eksperimental yang memberikan bukti bahwa asupan energi secara langsung meningkat setelah mengonsumsi diet tinggi lemak. ${ }^{40}$
Asupan protein berlebih lebih banyak dikonsumsi oleh remaja obesitas. Asupan protein akan mempengaruhi peningkatan energi yang masuk ke dalam tubuh. Terkait pengaruhnya terhadap gizi lebih, sama seperti karbohidrat, jika jumlah protein yang masuk ke dalam tubuh dalam jumlah yang berlebih maka akan mengalami deaminase. Nitrogen dikeluarkan dari tubuh dan sisa ikatan karbon akan diubah tubuh menjadi bentuk lemak dan kemudian disimpan dalam tubuh. Hal inilah yang akan menyebabkan kenaikan jaringan lemak yang berimbas kepada kenaikan berat badan dan akhirnya terjadilah status gizi lebih. Mekanisme kelebihan protein dalam tubuh serupa dengan mekanisme kelebihan karbohidrat dalam tubuh yaitu akan disimpan dalam tubuh dalam bentuk lemak. ${ }^{41}$

Asupan serat pada dua kelompok tidak menunjukkan adanya asupan serat yang berlebih, namun rerata asupan serat pada kelompok obesitas lebih tinggi dibandingkan dengan kelompok non obesitas. Dalam penelitian ini menunjukkan bahwa sumber serat yang diasup oleh kelompok obesitas banyak ditemukan pada jenis makanan utama seperti sayur yang sering dikonsumsi bersama nasi dan lauk. Makanan yang mengandung serat terkadang dilupakan oleh para remaja. Pola makan kebanyakan remaja sekarang ialah tinggi kalori namun rendah serat. Hal ini ternyata dapat memicu terjadinya kejadian status gizi lebih. Pada remaja ketidaksukaan akan sayuran dan buah merupakan faktor utama rendahnya asupan serat. ${ }^{42}$

Aktivitas fisik yang aktif lebih banyak ditemukan pada kelompok non obesitas. Dalam penelitian ini menunjukkan kelompok obesitas dan non obesitas membatasi melakukan aktifitas fisik karena selama seminggu terakhir akan menghadapi ujian tengah semester.Aktivitas fisik penting dilakukan pada masa remaja tidak hanya karena bisa mencegah dan mengurangi obesitas, namun juga dapat mengurangi risiko penyakit kardiovaskular dan diabetes tipe $2 .{ }^{43}$ Sejumlah faktor bisa berakibat pada keterbatasan aktivitas fisik baik di sekolah, seperti kendala anggaran dan tekanan untuk memenuhi target kinerja akademis yang mengurangi kegiatan non akademis seperti olahraga. Di luar sekolah, aktivitas fisik juga sering terbatas ditandai dengan penurunan drastis proporsi anak yag berjalan atau bersepeda ke sekolah, dari mendekati 42\% pada tahun 1969 menjadi $16 \%$ pada tahun $2001 .^{44}$

\section{SIMPULAN}

Terdapat perbedaan asupan energi cemilan dan kualitas tidur pada remaja obesitas dan non obesitas usia 15-18 tahun. Tidak terdapat perbedaan durasi tidur pada remaja obesitas dan non obesitas usia 15-18 tahun.Konsumsi energi cemilan 
memberikan kontribusi terhadap tingginya asupan energi, dan zat gizi makro lain.Kualitas tidur yang buruk menyebabkan kelelahan setelah bangun tidur, dan penurunan aktifitas fisik, sehingga terjadi peningkatan sedentary lifestyle.

\section{SARAN}

Konsumsi energi cemilan oleh remaja harus di perhatikan terutama dalam aspek keseimbangan energi antara asupan yang melebihi pengeluaran energi, dan juga harus memperhatikan kepuasan seseorang terhadap tidur, sehingga seseorang tersebut tidak memperlihatkan perasaan lelah, mudah terganggu, gelisah, lesu dan sering menguap atau mengantuk,yang dapat berpengaruh kepada aktifitas fisik. Bagi peneliti lain yang ingin melakukan penelitian serupa hendaknya melakukan pengukuran variabel tingkat stress dan frekuensi cemilan.

\section{UCAPAN TERIMAKASIH}

Terima kasih kepada seluruh responden dan pihak yang telah berpartisipasi dalam penelitian ini.

\section{DAFTAR PUSTAKA}

1. Biswas T, Islam A, Islam S, Pervin S, Rawal LB. Overweight and obesity among children and adolescents in Bangladesh : a systematic review and meta-analysis. Public Health. Elsevier Ltd. 2016;142:94-101.

2. Wang $Y$, Lobstein $T$. Worldwide trends in childhood overweight and obesity. International Journal of Pediatric Obesity. 2006;1:11-25.

3. Herouvi D, Karanasios E, Karayianni C, Karavanaki K.Cardiovascular disease in childhood: the role of obesity. Europa Journal of Pediatric.2013;172:721-32.

4. Foltz JL, May AL, Belay B, Nihiser AJ, Dooyema CA, Blanck HM. Population-level intervention strategies and examples for obesity prevention in children. American Journal of Clininical Nutrition. 2012;32:391-415.

5. Huriyati E. Studi Kohort Prevalensi Obesitas Siswa Siswi Sekolah Lanjutan Tingkat Pertama ( SLTP ) Kota Yogyakarta. Jurnal gizi klinik indonesia. 2006;3(1):53-7.

6. Bellisle F. Physiology \& Behavior Meals and snacking, diet quality and energy balance. Physiological Behavior. Elsevier.2014;134:3843.

7. Piernas C, Popkin BM. Trends in snacking among U.S. children. Health Aff 2010;29:398404.

8. Sonneville KR, Gortmaker, SL. Total energy intake, adolescent discretionary behaviors and the energy gap. International Journal of Obesity ( Lond 0 2008;32(6):19-27.

9. Falbe J, Willett WC, Rosner B, Gortmaker SL, Sonneville KR, Field AE. Longitudinal relations of television, electronic games, and digital versatile discs with changes in diet in adolescents. American Journal Of Clinical Nutrition;2014;100:1173-81.

10. Ournal THEJ, Ediatrics OFP. United States Adolescents' Television, Computer, Videogame, Smartphone, and Tablet Use: Associations with Sugary Drinks, Sleep, Physical Activity, and Obesity. The Journal of Pediatric. 2016; 182:144-182.

11. Jennifer L. Baker, Ph.D., Lina W. Olsen, Ph.D., and Thorkild I.A. Sørensen, M.D., Dr.Med.Sci. Childhood Body-Mass Index and the Risk of Coronary Heart Disease in Adulthood Index CB. new england journal of medicine. 2007;2329-37.

12. Menteri Kesehatan Republik Indonesia. Riset Kesehatan Dasar 2013.

13. Menteri Kesehatan Republik Indonesia. Riset Kesehatan Dasar 2010.

14. Rachmi CN, Li M, Baur LA. Overweight and obesity in Indonesia: prevalence and risk factors. literature review. 2017;7.

15. Ournal THEJ, Ediatrics OFP. United States Adolescents' Television, Computer, Videogame, Smartphone, and Tablet Use: Associations with Sugary Drinks, Sleep, Physical Activity, and Obesity. Journal of Pediatric Elsevier Inc.; 2016;182:144-9.

16. Musaiger AO, Al-roomi K, Bader Z. Social , dietary and lifestyle factors associated with obesity among Bahraini adolescents. Journal of Pediatric Elsevier .2014;73:197-204.

17. Bell AC, Swinburn BA. What are the key food groups to target for preventing obesity and improving nutrition in schools?. European Journal of Clinical Nutrition. 2007;58:258-263.

18. Fatima Y, Doi SAR, Mamun AA. Longitudinal impact of sleepon overweight and obesity in children and adolescents: asystematic review and bias-adjusted meta-analysis. Obesity review. 2015;16:137-49.

19. Wu Y, Gong Q, Zou Z, Li H, Zhang X. Short sleep duration and obesity among children : A systematic review and meta-analysis of prospective studies. Obesity Res Clinical Pract. Asia Oceania Association for the Study of Obesity.2016.

20. Lin $\mathrm{C}$, Lin $\mathrm{C}$, Chen $\mathrm{S}, \mathrm{Wu} \mathrm{H}$, Tsai Y. The association between sleep duration and overweight or obesity in Taiwanese adults: A cross-sectional study. Obesity Res Clinical 
Pract. Asia Oceania Association for the Study of Obesity. 2016.

21. Knutson KL,Spiegel K,Penev P,Van Cauter E.The metabolic consequences of sleep deprivation.Sleep Medication Review.2007;11:163-78

22. Ferranti R, Marventano S, Castellano $S$, Giogianni G, Nolfo F, Rametta S, et al. Sleep quality and duration is related with diet and obesity in young adolescent living in Sicily, Southern Italy. Sleep Scient. Elsevier. 2016;9(2):117-22.

23. Tonetti L, Fabbri M, Filardi M, Martoni M, Natale V. Effects of sleep timing, sleep quality and sleep duration on school achievement in adolescents. Sleep Medication. Elsevier. 2015;16(8):936-40.

24. Atikah, Ema K:Ilmu Gizi Untuk Keperawatan dan Gizi Kesehatan.Yogyakarta:Nuha Medika;2010.

25. Supariasa, I.D.N. dkk:Penilaian Status gizi (Edisi Revisi). Jakarta: Buku Kedokteran EGC;2013

26. Harvard T.H. CHAN School of public health. [ homepage on the Internet ]: How Much Physical Activity and Sleep Do Children and Teens Need ? c2017 [ updated 2017, Agustus 09].

27. Buysee,D.J., Reynolds,C.F., Monk,T.H., Berman,S.R., Kupfer,D.J.The Pittsburgh Sleep Quality Index (PSQI): a new instrument for psychiatric research and practice. Psychiatri Research. 1989;28(2):193-213

28. Guidelines for Data Processing and Analysis of the International Physical Activity Questionnaire (IPAQ)-Short and Long Forms. November 2005

29. Birch LL, Fisher JO, Davison KK. Learning to overeat: maternal use of restrictive feeding practices promotes girls' eating in the absence of hunger. American Journal of Clinical Nutrition. 2009; 78(2):215-220.

30. Hanley,A.J et al. Overweight Among Children And Adolescent In Native Cannadian Community : Prevalence And Assosiated Factor, The American Jounal of Clinical Nutition.2000;71:693-700.

31. Lowry R, et al. Television Viewing and Its Associations with Overweight, Sedentary Lifestyle, and Insufficient Consumption of Fruits and Vegetables among US High School Students : Differences by Race, Ethnicity, and Gender.Journal of School Health. 2002;72(10):413-421

32. Marsetyo H dan Kartasapoetra G. Ilmu Gizi (Korelasi Gizi, Kesehatan dan Produktivitas Kerja). Jakarta: Rineka Cipta. 2006.
33. Dahl RE, Lewin DS: Pathways to adolescent health: Sleep reg-ulation and behavior. Journal of Adolesc Health. 2009, 31:175-184.

34. Pilcher JJ, Ginter DR, Sadowsky B: Sleep quality versus sleep quantity: Relationship between sleep and measures of health, well being and sleepiness in college students.J Psycho Res 2008, 42: 583-596.

35. Asep S. Buku Ajar Farmakologi:Neurofarmakologi, Asetilkolin, dan Nore Efinefrin. Lampung:Fakultas Kedokteran Universitas Lampung;2014

36. Brown, Fc, Buboltz, Wc Jr, Soper B. Development And Evaluation Of The Sleep Treatment And Education Program For Students (Steps). Journal of American College Health,2006: 54:231-237.

37. Sendir M, Acaroglu R, Kaya H, Erol S, Akkaya Y. Evaluation of quality of sleep and effecting factors in hospitalized neurosurgical patients. Neurosciences. 2007; 12: 226-31.

38. Ana M, Hamam H. Hubungan antara asupan energi, asupan lemak, dan obesitas pada remaja SLTP di Kota Yogyakarta. Jurnal gizi klinik Indonsia.2005:1(3):119-129

39. Sediaoetama, Achmad Djaenia. Ilmu Gizi unutk Mahasiswa dan profesi. Jakarta: Dian Rakyat; 2008.

40. Butte, N E.,et al. Metabolic and Behavioural Predictors of weight Gain in Hispanic Children:The Viva La Lamilia Study. American Journal of Clinical Nutrition. 2007;85(6):14781485.

41. Wilson, T A., et al. Nutrient Adequacy and Diet Quality in Non Overweight and Overweight Hispanic Children of Low Socioeconomic status : The Viva la Familia Study. Journal of the American Dietetic Association; 2009 109(6):1012-1021.

42. Brown, Judith E. Nutrition throught the life cycle 2nd ed. USA : Thomson-Wadsworth.2005

43. Prevalence of physical activity, including lifestyle activities among adults - United States, 2000-2001. MMWR Morb Mortal Wkly Rep 2007;52:764-9

44. Kimm SY, Glynn NW, Kriska AM, et al. Decline in physical activity in black girls and white girls during adolescence. National England Journal of Medication. 2008;347:70915. 